\title{
Cloning, expression and characterization of an aryl-alcohol dehydrogenase from the white-rot fungus Phanerochaete chrysosporium strain BKM-F-1767
}

Dong-Dong Yang ${ }^{1,2,3}$, Jean Marie François ${ }^{1,2,3}$ and Gustavo M de Billerbeck ${ }^{1,2,3,4^{*}}$

\begin{abstract}
Background: The white-rot fungus Phanerochaete chrysosporium is among the small group of fungi that can degrade lignin to carbon dioxide while leaving the crystalline cellulose untouched. The efficient lignin oxidation system of this fungus requires cyclic redox reactions involving the reduction of aryl-aldehydes to the corresponding alcohols by aryl-alcohol dehydrogenase. However, the biochemical properties of this enzyme have not been extensively studied. These are of most interest for the design of metabolic engineering/synthetic biology strategies in the field of biotechnological applications of this enzyme.

Results: We report here the cloning of an aryl-alcohol dehydrogenase cDNA from the white-rot fungus Phanerochaete chrysosporium, its expression in Escherichia coli and the biochemical characterization of the encoded GST and His 6 tagged protein. The purified recombinant enzyme showed optimal activity at $37^{\circ} \mathrm{C}$ and at pH 6.4 for the reduction of aryl- and linear aldehydes with NADPH as coenzyme. NADH could also be the electron donor, while having a higher $\mathrm{Km}(220 \mu \mathrm{M})$ compared to that of NADPH $(39 \mu \mathrm{M})$. The purified recombinant enzyme was found to be active in the reduction of more than 20 different aryl- and linear aldehydes showing highest specificity for mono- and dimethoxylated Benzaldehyde at positions 3, 4, 3,4 and 3,5. The enzyme was also capable of oxidizing aryl-alcohols with $\mathrm{NADP}^{+}$at $30^{\circ} \mathrm{C}$ and an optimum pH of 10.3 but with 15 to 100 -fold lower catalytic efficiency than for the reduction reaction.
\end{abstract}

Conclusions: In this work, we have characterized the biochemical properties of an aryl-alcohol dehydrogenase from the white-rot fungus Phanerochaete chrysosporium. We show that this enzyme functions in the reductive sense under physiological conditions and that it displays relatively large substrate specificity with highest activity towards the natural compound Veratraldehyde.

Keywords: AAD, Aryl-alcohol dehydrogenase, Lignocellulosic hydrolysates, Lignin, Flavours, Fragrances, Phanerochaete chrysosporium

\footnotetext{
* Correspondence: debiller@insa-toulouse.fr

'Université de Toulouse; INSA, UPS, INP; LISBP, 135 Avenue de Rangueil,

Toulouse F-31077, France

${ }^{2}$ INRA, UMR792 Ingénierie des Systèmes Biologiques et des Procédés,

Toulouse F-31400, France

Full list of author information is available at the end of the article
} 


\section{Background}

Lignin is, after cellulose, the second most abundant terrestrial biopolymer, accounting for approximately $30 \%$ of the organic carbon in the biosphere [1]. The biodegradation of lignin plays a crucial role in the earth's carbon cycle. Unlike cellulose and hemicellulose, this amorphous and insoluble aromatic material lacks stereoregularity and is not susceptible to hydrolytic attack. In nature, the white-rot fungus Phanerochaete chrysosporium is among the small group of fungi that can completely degrade lignin to carbon dioxide while leaving the crystalline cellulose untouched [2].

Lignin degradation by $P$. chrysosporium is initiated by an array of extracellular oxidases and peroxidases, such as the multiple isoenzymes of lignin peroxidase (LiP) and manganese-dependent peroxidase (MnP) [3-6]. Both LiP and $\mathrm{MnP}$ require extracellular $\mathrm{H}_{2} \mathrm{O}_{2}$ for their catalytic activity. One likely source of $\mathrm{H}_{2} \mathrm{O}_{2}$ is the copper radical oxidases, such as glyoxal oxidase [7-9]. In addition to the copper radical oxidases, the FAD-dependent extracellular aryl-alcohol oxidases (Aaop) catalyze the oxidation of arylalcohol derivatives into their corresponding aldehydes with the concomitant reduction of $\mathrm{O}_{2}$ to $\mathrm{H}_{2} \mathrm{O}_{2}[6,10]$. The Aaop substrates, like the physiologically-significant secondary metabolite 3,4-Dimethoxybenzyl (Veratryl) alcohol [11], can originate, firstly, through de novo biosynthesis [12] and secondly, through reduction of aromatic aldehydes released during lignin degradation in cyclic redox reactions involving also aryl-alcohol dehydrogenase (Aadp) [13-17]. Furthermore, the identification of the Veratryl alcohol binding site in LiP [18] confirms the presumption that this alcohol also serves as a redox mediator for LiP-catalyzed depolymerization of lignin [11].

By following the reduction of 3,4-Dimethoxybenzaldehyde (Veratraldehyde) in Nitrogen-limited cultures of P. chrysosporium, Muheim et al. [19] purified an intracellular aryl-alcohol dehydrogenase (EC 1.1.1.91) from this lignin-degrading fungus. A cDNA coding for this protein was later isolated and characterized [20]. However, the biochemical properties of the Aadp enzyme were not extensively studied.

Due to its high efficiency in lignin degradation, and to its potential applications in the textile, fuel and paper industries, the $35-\mathrm{Mb}$ haploid genome of $P$. chrysosporium strain RP78 has been sequenced [2]. The current draft release, version 2.0, includes a total of 10,048 gene models [21] and reveals that the secreted oxidases, peroxidases and hydrolytic enzymes that cooperate in wood decay exist as large multi-gene families. Taking advantage of this genome sequence, this work describes the cloning of an $A A D$ cDNA and the comprehensive biochemical characterization of the encoded enzyme in order to get deeper insight into its biological relevance and biotechnological applications potential such as the degradation of aromatic inhibitors in lignocellulosic hydrolysates that strongly impair ethanol fermentation by yeast [22], as well as for the microbial production of natural flavour and fragrance molecules like 2-Phenylethanol.

\section{Results and discussion \\ Cloning of a cDNA from Phanerochaete chrysosporium encoding an aryl-alcohol dehydrogenase}

Using the amino acid sequence coded by a previously cloned $A A D$ ORF from Phanerochaete chrysosporium $(P c)$ strain OGC101 [20] as query, a BLAST alignment was performed against the translated predicted ORFs of the genome sequence of $P$. chrysosporium strain RP78 $[2,21]$. The results showed the existence of $8 A A D$ homologues that consist of six to nine exons and encode proteins from 240 to 398 amino acids. The presence of multiple $A A D$ genes in the $P c$ genome is in accordance with strong multiple bands observed in a Southern blot by Reiser et al. [20]. Interestingly, in scaffold_1, two tandem $A A D$ homologues (scaffold_1:1025231 to 1023962, and scaffold_1:1027063 to 1025827) were found adjacent to each other. The distance between these two adjacent ORFs is only 596 base-pairs. This extensive genetic diversity was also observed for other lignin-biodegradation related genes encoding peroxidases, oxidases, glycosydases and cytochrome P450s [2]. The existence of multiple $A A D$ genes might suggest multiple specificities required to reduce various aryl-aldehydes arising from the catabolism of complex wood polymers.

Among the 8 predicted homologous ORFs in the genome of Pc strain RP78, the one in scaffold_3:22357042237287 (JGI Transcript Id: 11055) has only 37 base pairs differences with the cDNA previously cloned by Reiser et al. [20] and encodes a 100\% identical amino acid sequence. Considering that the remaining $7 A A D$ homologues show 72.1, 66.7, 64.6, 55, 54.1, 49.9 and $45.7 \%$ amino acid identity with this cDNA sequence, we designed specific primers on the coding region from scaffold_3:2235704-2237287 (hereafter termed AAD1) to clone the full length cDNA using RACE (rapid amplification of cDNA ends, [23,24]) and PCR techniques. The method was adopted because of the presence of 5 introns in the genomic sequence of this PC AAD1 gene. The RNA used for this cloning was obtained from a six days Nitrogen-limited culture of Pc strain BKM-F-1767. As shown in Figure 1, qPCR assays under this growth condition showed that the $A A D 1$ transcript began to accumulate at day 2 and continued over 6 days. This result nicely correlated with an increase of aryl-alcohol dehydrogenase activity acting on Veratraldehyde during $\mathrm{N}$-limited culture and reaching a maximum after 6 days of growth [19]. The RACE-PCR method on the 6-days purified RNA allowed us to isolate a 1.4 kilobase fulllength cDNA containing a 1155 bp ORF that encoded a 


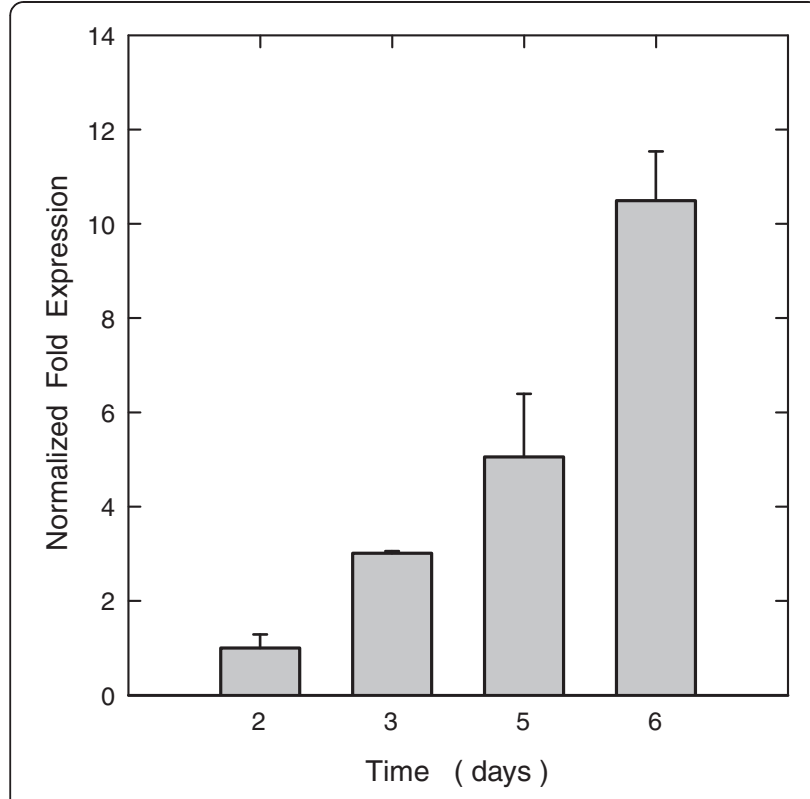

Figure 1 Expression of $P C A A D 1$ gene during Nitrogen-limited cultivation. The PC AAD1 transcript level was evaluated by real-time PCR with $\beta$-Tubulin as reference gene. Day 2 sample was taken as the calibrator sample. Results are the mean \pm SEM from technical triplicates of four biological replicates.

protein $100 \%$ identical with the translated genomic sequence from $P_{c}$ RP78 strain $[2,21]$ as well as with that of Reiser et al. [20]. The sequencing results of the cloned Pc AAD1 cDNA also showed the presence of a $5^{\prime}$ untranslated region (UTR) and of a $3^{\prime}$ poly(A) tail, confirming the integrity of the mRNA template. Comparison of the 5'UTR (159 nucleotides in total) with that of the cDNA by Reiser et al. [20] revealed 94.3\% nucleotide identity, suggesting they are the same gene in the two strains.

\section{Heterologous expression in E. Coli and purification of recombinant Pc Aad1p}

In order to obtain large amounts of purified recombinant enzyme for biochemical characterization, the Pc AAD1 ORF was cloned in pGS-21a and pGEX-6p-1 vectors and expressed in E. coli to produce GST and/or $\mathrm{His}_{6}$ tagged proteins. The expression conditions were optimized using different $E$. coli strains, cultivation temperatures, IPTG concentrations and induction times. The highest accumulation of recombinant Pc Aad1p was obtained with E. coli BL21 $\operatorname{Star}^{\mathrm{TM}}(\mathrm{DE} 3)$ strain harbouring the pGS-21a-AAD1 expression vector after overnight induction with $0.1 \mathrm{mM}$ IPTG at $16^{\circ} \mathrm{C}$ allowing the production of up to $1.8 \pm 0.1 \mathrm{~g} \cdot \mathrm{L}^{-1}$ of recombinant protein after purification. After cell disruption, the recombinant Aad1p was purified by Glutathione affinity chromatography to yield a single protein band as shown on SDS-Polyacrylamide gel electrophoresis (Figure 2, lane 3). This SDS-PAGE also showed that the recombinant protein was the major band in the cell lysate (Figure 2, lane 1) and that the purified protein migrates at an apparent molecular mass of $70 \mathrm{kDa}$ in our conditions of electrophoresis. Taking into account the presence of the GST and $\mathrm{His}_{6}$ tags in the fusion protein, which correspond to $\sim 30 \mathrm{kDa}$, the molecular mass of our purified Pc Aad1p is in accordance with the theoretical molecular mass calculated from its amino acid composition (43 kDa) and very close to the apparent $47 \mathrm{kDa}$ of the Aad enzyme purified from P. chrysosporium by Muheim et al. [19].

\section{Biochemical characterization of the purified recombinant Pc Aad1p Structure analysis of Pc Aad1p}

We searched for functional domains of the Pc Aad1 protein using the Pfam database server $[25,26]$. This in silico analysis identified the protein as belonging to subfamily AKR9A of the aldo-keto reductase (AKR) superfamily with residues D71, Y76 and K103 as predicted activesites. The AKR superfamily is one of the three enzyme superfamilies that perform oxidoreduction on a wide variety of natural and foreign substrates [27]. The large AKR superfamily includes presently 15 families, with more than 170 proteins identified in mammals, plants, fungi and bacteria. AKR structures share a highly conserved $(\alpha / \beta)_{8}$-barrel motif, a conserved cofactor (mostly NADPH) binding site and catalytic tetrad, and a variable loop structure

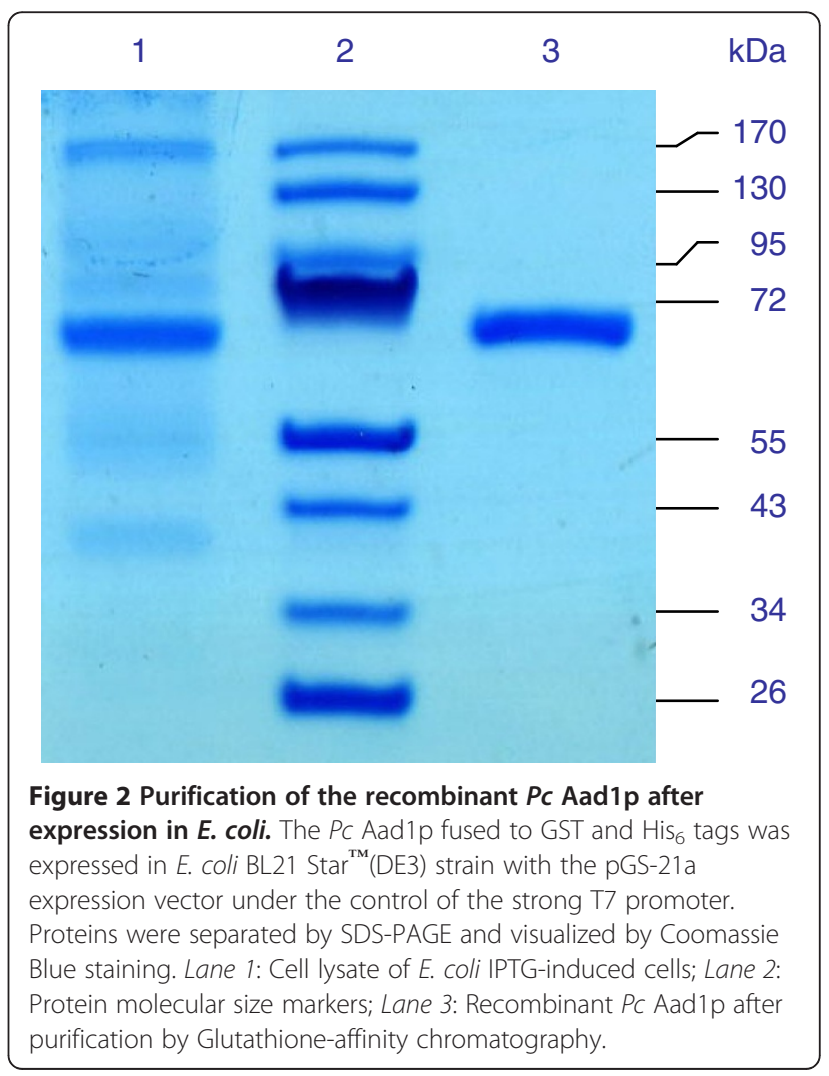


which usually defines broad substrate specificity. The majority of AKRs are monomeric proteins of about 320 amino acids in length, although several members from families AKR2, AKR6 and AKR7 were found to form multimers [28]. The closest AKR protein 'relatives' of $P c$ Aad1p (AKR9A3) are the fungal norsolorinic acid reductase from Aspergillus flavus (AKR9A2) and sterogmatocystin dehydrogenase from Aspergillus nidulans (AKR9A1) and the putative yeast proteins Aad14p, Aad3p, Aad4p and Aad10p from Saccharomyces cerevisiae. According to the family tree structure, the nearest AKR with 3D structure characterized is AKR11C1 from the bacterium Bacillus halodurans [27,29]. Aldo-keto reductases catalyze oxidation and reduction reactions on a range of substrates using $\operatorname{NAD}(\mathrm{P})(\mathrm{H})$ as cofactor. An ordered Bi Bi kinetic mechanism, in which cofactor binds first and leaves last, has been demonstrated for pig kidney aldehyde reductase (ALR) [30], bovine kidney aldose reductase ADR [31], rat

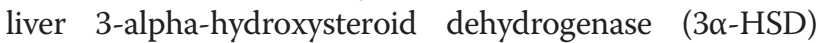
[32] and 3-oxo-5b-steroid 4-dehydrogenase [33], and may be a characteristic feature of other AKRs [34]. The reduction reaction involves 4-pro- $\mathrm{R}$ hydride transfer from $\mathrm{NAD}(\mathrm{P}) \mathrm{H}$ to the substrate carbonyl and protonation of the Oxygen by a residue of the enzyme acting as a general acid [34]. The rate of this reaction is increased with substrates harbouring chemical structures that facilitate their nucleophilic attack by the hydride ion. It is also influenced by the orientation and/or relative mobility of the carbonyl function with respect of the rest of the molecule that would affect its protonation by one or more possibly acid residues of the active site.

\section{Temperature- and $\mathrm{pH}$-dependence of Pc Aad1p activity}

To determine $\mathrm{pH}$ and temperature optimum of the recombinant purified $P_{c}$ Aad1p, we used Veratraldehyde as substrate for the reductive sense, and the corresponding alcohol for the oxidative sense of the reaction, while $\mathrm{NADP}(\mathrm{H})$ was used as the cofactor. As shown in Figure $3 \mathrm{~A}$, the activity of this enzyme was optimal at about $\mathrm{pH} 6.4$ in the reductive sense whereas oxidation rates could only be measured in basic conditions with an optimum at $\mathrm{pH}$ 10.4. At this $\mathrm{pH}$, the oxidation activity was 7 -fold lower than at the optimal $\mathrm{pH}$ for the reductive reaction. These results strongly support the fact that the Pc Aad1p works in the cells predominantly as an aldehyde reductase. The optimal temperature for activity was only determined in the reductive sense and was found to be close to $37^{\circ} \mathrm{C}$ (Figure 3B).

\section{Substrate specificity and kinetic properties of Pc Aad1p}

The substrate specificity of the purified recombinant $P c$ Aad1p protein was determined with a large spectrum of chemical molecules including linear aliphatic and arylaldehydes and alcohols, and ethyl-, ramified and aryl acetate esters (Table 1), keeping in mind that the presence of a GST tag at the amino terminus could modify the enzyme properties. Figure 4 shows some of the aldehyde and alcohol substrates analyzed in this study ordered by chemical function and substitution. For comparative analysis, we carried out our assays at pH 6.1 in $50 \mathrm{mM}$ MES and at $30^{\circ} \mathrm{C}$ using the same concentration of substrate molecules and NADPH and compared the measured activity to that obtained with Veratraldehyde, which was used as the reference. The activity value with this substrate was set to 100\%. As indicated in Table 1, Pc Aad1p activity with mono-methoxylated Benzaldehyde at positions 3 (meta) or 4 (para), or dimethoxylated at positions 3,5 was very close or even slightly higher than with Veratraldehyde (3,4-Dimethoxybenzaldehyde). Activity was reduced by two when the methoxy radical was on carbon 2 (ortho). The presence of a hydroxyl group on Benzaldehyde or on methoxy-substituted Benzaldehyde resulted in a dramatic drop of the activity of $P c$ Aadlp. Likewise, the enzyme was 3 to 5 -fold less active on other types of substitutions of the Benzaldehyde molecule such as with Chlorine, Fluorine or Nitro functional groups. Furthermore, the Pc Aad1p activity on Phenylacetaldehyde was comparable to that of Veratraldehyde. Linear aldehydes of 3 to 11 carbon atoms were also assayed for substrate specificity of $P c$ Aad1p. The highest activity was observed on $\mathrm{C} 6$ to $\mathrm{C} 8$ aldehydes, with reaction rates about 2-fold lower than on Veratraldehyde but comparable to that on Benzaldehyde. No activity was detected for Propanal (C3) and Butanal (C4) and very low activity for $\mathrm{C} 9$ to $\mathrm{C} 11$ aldehydes.
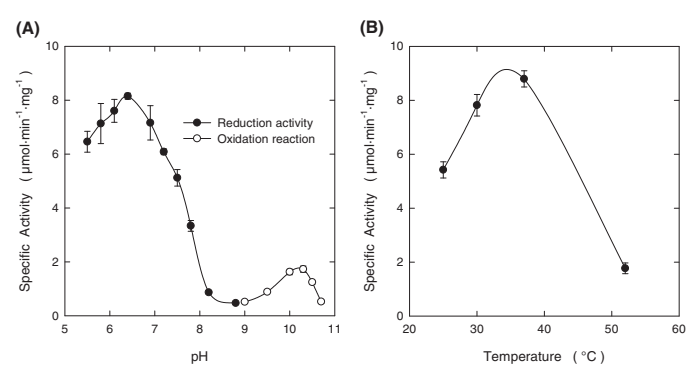

Figure $3 \mathrm{pH}$ and temperature dependence of recombinant $P c$ Aad1p activity. (A) Effect of $\mathrm{pH}$ in reduction and oxidation reactions. Reduction activities were measured at $\mathrm{pH}$ 5.5-8.8 with $0.2 \mathrm{mM}$ NADPH and $0.2 \mathrm{mM}$ 3,4-Dimethoxybenzaldehyde. Oxidation reactions were performed at $\mathrm{pH}$ 9.0-10.7 using $0.3 \mathrm{mM} \mathrm{NADP}^{+}$and $10 \mathrm{mM}$ 3,4-Dimethoxybenzyl alcohol. Reactions were carried out at $30^{\circ} \mathrm{C}$. (B) Effect of temperature on the reduction activity of recombinant $P C$ Aad1 $\mathrm{p}$. Activity was measured at $\mathrm{pH} 6.1$ with $\mathrm{NADPH}$ and 3,4-Dimethoxybenzaldehyde at $0.2 \mathrm{mM}$ final concentration. The reaction was started by adding $9.0 \mu \mathrm{g}$ of the enzyme. Results are the mean \pm SEM from two separate experiments. 
Table 1 Substrate specificity of the recombinant Aad1p from Phanerochaete chrysosporium

\begin{tabular}{|c|c|c|c|}
\hline Reduction & Activity (\%) & Oxidation & Activity (\%) \\
\hline Linear aliphatic aldehydes & & Aryl-alcohols & \\
\hline Propanal (C3) & nd & 4-Methoxybenzyl alcohol & 15 \\
\hline Butanal (C4) & nd & 3,4-Dimethoxybenzyl alcohol & 100 \\
\hline Pentanal (C5) & 8 & 3,5-Dimethoxybenzyl alcohol & 3 \\
\hline Hexanal (C6) & 47 & 3,4,5-Trimethoxybenzyl alcohol & 5 \\
\hline Heptaldehyde (C7) & 26 & 4-Hydroxybenzyl alcohol & 3 \\
\hline Octanal (C8) & 37 & 3-Hydroxy-4-methoxybenzyl alcohol & 8 \\
\hline Nonanal(C9) & 3 & 4-Hydroxy-3-methoxybenzyl alcohol & 46 \\
\hline Decanal (C10) & 2 & & \\
\hline Undecanal (C11) & 1 & & \\
\hline Aryl-aldehydes & & No detectable activity & \\
\hline Benzladehyde & 42 & Linear aliphatic alcohols & \\
\hline 2-Methoxybenzaldehyde & 58 & Ethanol (C2) & \\
\hline 3-Methoxybenzaldehyde & 117 & Propanol (C3) & \\
\hline 4-Methoxybenzaldehyde & 110 & Butanol (C4) & \\
\hline 3,4-Dimethoxybenzaldehyde & 100 & Pentanol (C5) & \\
\hline 3,5-Dimethoxybenzaldehyde & 110 & Hexanol (C6) & \\
\hline 4-Hydroxybenzaldehyde & 34 & Octanol (C8) & \\
\hline 3-Hydroxy-4-methoxybenzaldehyde & 17 & Nonanol (C9) & \\
\hline 4-Hydroxy-3-methoxybenzaldehyde & 19 & Decanol (C10) & \\
\hline 3-Chlorobenzaldehyde & 73 & Undecanol (C11) & \\
\hline 4-Chlorobenzaldehyde & 61 & Ramified aliphatic alcohols & \\
\hline 2-Nitrobenzaldehyde & 57 & 2-Methylpropanol (C4) & \\
\hline 3-Nitrobenzaldehyde & 25 & 2-Methylbutanol (C5) & \\
\hline 4-Nitrobenzaldehyde & 31 & Aryl-alcohols & \\
\hline 2-Fluorobenzaldehyde & 27 & Benzyl alcohol & \\
\hline 3-Fluorobenzaldehyde & 69 & 2-Methylbenzyl alcohol & \\
\hline 4-Fluorobenzaldehyde & 29 & 3-Methylbenzyl alcohol & \\
\hline Phenylacetaldehyde & 109 & 4-Methylbenzyl alcohol & \\
\hline trans-Cinnamaldehyde & 39 & 2-Methoxybenzyl alcohol & \\
\hline Others & & 3-Methoxybenzyl alcohol & \\
\hline \multirow[t]{2}{*}{ 5-(Hydroxymethyl)-2-furaldehyde } & 36 & 2-Chlorobenzyl alcohol & \\
\hline & & 4-Chlorobenzyl alcohol & \\
\hline No detectable activity & & 2-Nitrobenzyl alcohol & \\
\hline Aryl-acid & & 3-Nitrobenzyl alcohol & \\
\hline Phenylacetic acid & & 4-Nitrobenzyl alcohol & \\
\hline Ethyl-esters & & 2-Fluorobenzyl alcohol & \\
\hline Ethyl hexanoate & & 3-Fluorobenzyl alcohol & \\
\hline Ethyl octanoate & & 4-Fluorobenzyl alcohol & \\
\hline Ethyl decanoate & & 2-Phenylethanol & \\
\hline Ramified and aryl acetate esters & & trans-Cinnamyl alcohol & \\
\hline 2-Methylpropyl acetate & & Aryl-acid & \\
\hline 2-Methylbutyl acetate & & Phenylacetic acid & \\
\hline
\end{tabular}




\title{
Table 1 Substrate specificity of the recombinant Aad1p from Phanerochaete chrysosporium (Continued)
}

3-Methylbutyl acetate
2-Phenylethyl acetate
Others
L-Glutathione oxidized

\author{
Ethyl-esters \\ Ethyl hexanoate \\ Ethyl octanoate \\ Ethyl decanoate \\ Ramified and aryl acetate esters \\ 2-Methylpropyl acetate \\ 2-Methylbutyl acetate \\ 3-Methylbutyl acetate \\ 2-Phenylethyl acetate
}

Results are the mean of three separate experiments with relative SEM being lower than $6 \%$.

Among the substrates assayed for the oxidation reaction by Pc Aad1p with $\mathrm{NADP}^{+}$as cofactor, the highest activity was by far that on Veratryl alcohol (3,4-Dimethoxybenzyl alcohol), whereas other mono-, di- or tri-substituted methoxybenzyl alcohols showed poor reactivity with this enzyme. Interestingly, the $P c$
Aad1p showed $46 \%$ activity on 4-Hydroxy-3-Methoxybenzyl alcohol (Vanillyl alcohol) as compared to that on Veratryl alcohol. No activity could be detected on many other linear aliphatic, ramified aliphatic or aryl alcohol substrates as well as on some acetate esterified aryl and ramified alcohols. Altogether, these<smiles>CCCCCC=O</smiles>

n-Hexanal<smiles>COc1cccc(C=O)c1</smiles>

3-Methoxybenzaldehyde<smiles>COc1ccc(C=O)cc1OC</smiles>

3,4-Dimethoxybenzaldehyde<smiles>O=Cc1ccc(CO)o1</smiles>

5-(Hydroxymethyl)-2-furaldehyde<smiles>O=Cc1ccccc1</smiles>

Benzaldehyde<smiles>O=Cc1cccc(Cl)c1</smiles>

3-Chlorobenzaldehyde<smiles>O=CCc1ccccc1</smiles>

2-Phenylacetaldehyde<smiles>COc1ccc(CO)cc1OC</smiles><smiles>O=Cc1ccccc1[N+](=O)[O-]</smiles>

2-Nitrobenzaldehyde<smiles>O=Cc1ccc(O)cc1</smiles>

4-Hydroxybenzaldehyde<smiles>O=C/C=C/c1ccccc1</smiles>

Trans-Cinnamaldehyde<smiles>COc1cc(CO)ccc1O</smiles>

3,4-Dimethoxybenzyl alcohol 4-Hydroxy-3-methoxybenzyl alcohol

Figure 4 Chemical structures of several substrates of recombinant Pc Aad1p. Chemical structure of some of the aldehyde and alcohol substrates of Pc Aad1p analyzed in this study ordered by chemical function and substitution: aliphatic aldehydes (n-Hexanal), aryl-aldehydes (Benzaldehyde and related compounds, 2-Phenylacetaldehyde and trans-Cinnamaldehyde) and aryl-alcohols. Other substrates are presented in Table 1 and 2. 
results suggest that a specific size, structure and conformation of the substrate are necessary to allow concurrent interactions of the carbonyl group of the substrate molecule with the cofactor and with key amino acids of the active site. Other parameters like the relative hydrophilic/hydrophobic character of the substrates and of the active site as well as the possibility of resonance delocalization within a conjugated $\pi$ system of the substrate might also account for relative specificity of the Aad1p enzyme to its substrate.

We then obtained precise kinetic parameters of $P c$ Aad1p with respect to cofactor dependency and affinity to several substrates like Veratraldehyde or Veratryl alcohol (Table 2). In the reductive sense, using $0.2 \mathrm{mM}$ Veratraldehyde, the activity of $P c$ Aad1p for NADPH oxidation followed a Michaelis-Menten curve with an apparent $K_{M}=39 \mu \mathrm{M}$. NADH could also be used as electron donor though exhibiting a lower affinity $\left(K_{M}=220 \mu \mathrm{M}\right)$. The enzyme was only active with $\mathrm{NADP}^{+}$in the oxidation sense of the reaction, with a $K_{M}$ of $38 \mu \mathrm{M}$. Moreover, the activity of this enzyme determined against Veratraldehyde or Veratryl alcohol using NADPH or $\mathrm{NADP}^{+}$as cofactor showed a slight inhibition at elevated concentration of substrate (Figure 5). However, the apparent $K_{M}$ for Veratraldehyde was 30-fold that for Veratryl alcohol. This explained also that the catalytic efficiency $k_{c a t} / K_{M}$ of $P c$ Aad1p was about 100 -fold higher in the reductive than in oxidative sense of the reaction. Reduction activity towards Veratraldehyde has also been described for the enzymes Adh6p and Adh7p from the yeast Saccharomyces cerevisiae [35-37].

\section{Conclusion}

This study describes the cloning and biochemical properties of an aryl-alcohol dehydrogenase of the white-rot fungus Phanerochaete chrysosporium. It also shows its wide spectrum of activity on various chemicals (natural and non-natural) such as linear aliphatic and aryl-aldehydes, as well as its preference to function in the reductive sense under physiological conditions. This enzyme can be considered in the design of metabolic engineering strategies/synthetic biology systems for biotechnological applications such as the degradation of aromatic inhibitors present in lignocellulosic hydrolysates that impair yeast fermentation, or the microbial production of natural flavours and fragrances like the rose-like flavour compound 2-Phenylethanol. Further studies on the crystal structure of the protein and the determination of the key amino acids in its active site would be extremely

Table 2 Kinetic parameters of the recombinant Aad1p from Phanerochaete chrysosporium

\begin{tabular}{|c|c|c|c|c|}
\hline & $\begin{array}{l}\mathrm{K}_{M} \\
\mu \mathrm{M}\end{array}$ & $\begin{array}{c}\mathrm{K}_{\text {cat }} \\
\mathrm{min}^{-1}\end{array}$ & $\begin{array}{c}\mathbf{k}_{c a t} / \mathrm{K}_{M} \\
\mu \mathrm{M}^{-1} \cdot \mathrm{min}^{-1}\end{array}$ & $\begin{array}{c}K_{i} \\
\mu M\end{array}$ \\
\hline \multicolumn{5}{|l|}{ Substrates } \\
\hline \multicolumn{5}{|l|}{ Reduction } \\
\hline 3,4-Dimethoxybenzaldehyde & $12 \pm 2$ & $530 \pm 25$ & $44 \pm 9$ & $3400 \pm 1100$ \\
\hline 3,5-Dimethoxybenzaldehyde & $22 \pm 4$ & $590 \pm 30$ & $27 \pm 6$ & $2100 \pm 600$ \\
\hline 4-Methoxybenzaldehyde & $90 \pm 10$ & $490 \pm 10$ & $5.4 \pm 0.7$ & ni \\
\hline 5-(Hydroxymethyl)-2-furaldehyde & $270 \pm 40$ & $176 \pm 6$ & $0.65 \pm 0.12$ & $136000 \pm 28000$ \\
\hline Phenylacetaldehyde & $530 \pm 90$ & $670 \pm 25$ & $1.3 \pm 0.3$ & ni \\
\hline 3-Hydroxy-4-methoxybenzaldehyde & $1400 \pm 900$ & $230 \pm 110$ & $0.16 \pm 0.18$ & $2300 \pm 1800$ \\
\hline 4-Hydroxy-3-methoxybenzaldehyde & $1400 \pm 600$ & $200 \pm 50$ & $0.14 \pm 0.10$ & $5100 \pm 2300$ \\
\hline Benzaldehyde & $1700 \pm 600$ & $430 \pm 50$ & $0.3 \pm 0.1$ & $81000 \pm 44000$ \\
\hline trans-Cinnamaldehyde & $3400 \pm 1300$ & $670 \pm 200$ & $0.2 \pm 0.1$ & $3500 \pm 1600$ \\
\hline \multicolumn{5}{|l|}{ Oxidation } \\
\hline 3,4-Dimethoxybenzyl alcohol & $370 \pm 50$ & $153 \pm 6$ & $0.41 \pm 0.07$ & $165000 \pm 31000$ \\
\hline 4-Hydroxy-3-methoxybenzyl alcohol & $25000 \pm 7000$ & $260 \pm 60$ & $0.010 \pm 0.005$ & ni \\
\hline \multicolumn{5}{|l|}{ Coenzymes } \\
\hline \multicolumn{5}{|l|}{ Oxidation } \\
\hline NADPH & $39 \pm 5$ & $680 \pm 30$ & $17 \pm 3$ & ni \\
\hline $\mathrm{NADH}$ & $220 \pm 130$ & $120 \pm 40$ & $0.6 \pm 0.5$ & ni \\
\hline \multicolumn{5}{|l|}{ Reduction } \\
\hline $\mathrm{NADP}^{+}$ & $38 \pm 7$ & $154 \pm 7$ & $4.1 \pm 0.9$ & ni \\
\hline $\mathrm{NAD}^{+}$ & nd & nd & nd & nd \\
\hline
\end{tabular}

nd: no detectable activity under the conditions of the assay. ni: no inhibition detected. 
helpful for implementing protein engineering strategies in order to modify or improve the kinetic parameters of the enzyme.

\section{Materials and methods Materials}

DNA oligonucleotides were synthesized by Eurogentec (Seraing, Belgium). Phusion ${ }^{\circledR}$ High fidelity DNA polymerase, Taq DNA polymerase, restriction enzymes and T4 DNA ligase were from New England Biolabs (Ozyme, Saint-Quentin-en-Yvelines, France). dNTPs were from Eurogentec (Seraing, Belgium). Plasmids were sequenced by Beckman Coulter Genomics (Grenoble, France). Bacterial and fungus culture media were from Difco (Detroit, MI, USA). Glutathione Sepharose $^{\mathrm{TM}}$ 4B was from GE Healthcare Bio-Sciences AB (Uppsala, Sweden). Lysozyme and reduced and oxidized L-Glutathione were from Sigma-Aldrich Chimie SARL (Saint-Quentin Fallavier, France). SDS-PAGE gels were made with proteomics grade NEXT GEL 12.5\% acrylamide solution from AMRESCO (Solon, OH, USA). PageBlue ${ }^{\mathrm{TM}}$ protein staining solution and PageRuler $^{\text {TM }}$ (cat. \#SM0671) protein molecular size markers were from Fermentas (Thermo Electron SAS, Villebon sur Yvette, France). QIAquick Gel Extraction Kit was employed for purifying PCR products from gels. Plasmid extraction was done with QIAprep Spin Miniprep kit (Qiagen SAS, Courtaboeuf, France). Chemical substrates were purchased at highest available purity from Sigma-Aldrich Chimie SARL (Saint-Quentin-Fallavier, France). Unless otherwise specified, all other products were from Sigma-Aldrich Chimie SARL. Protein concentration was determined with the Bio-Rad Protein Assay (Bio-Rad, Marnes-la-Coquette, France) based on the Bradford method [38] using bovine serum albumin as calibration standard. Crude and purified protein extracts were analyzed by SDS-PAGE and visualised by Coomassie blue staining.

\section{Strain and growth conditions}

The white-rot basidiomycete Phanerochaete chrysosporium BKM-F-1767 strain used in this study (CBS 481.73) was purchased from Centraalbureau voor Schimmelcultures (Utrecht, Netherlands) in the form of a freeze-dried fungal culture. The mycelium was inoculated on freshly prepared Difco $^{\mathrm{TM}}$ Potato Dextrose Agar (PDA) plates and incubated at $37^{\circ} \mathrm{C}$ for four days before storage and maintenance at $4^{\circ} \mathrm{C}$ on PDA plates or at $-80^{\circ} \mathrm{C}$ in $30 \%$ glycerol for longterm preservation. Spore suspensions were prepared after 4-days propagation at $37^{\circ} \mathrm{C}$ on PDA plates by washing the agar surface with $10 \mathrm{~mL}$ of $50 \mathrm{mM}$ sodium acetate buffer at $\mathrm{pH}$ 4.5. Spore counts were determined with a counting chamber Thoma double cell.

To induce $A A D 1$ expression in $P$. chrysosporium, $600 \mathrm{~mL}$ of Nitrogen-limited liquid medium was inoculated at $10^{4}$ spores. $\mathrm{mL}^{-1}$ in a $1 \mathrm{~L}$ Erlenmeyer flask and cultivated at $37^{\circ} \mathrm{C}$ and $150 \mathrm{rpm}$ on a TR-225 rotary shaker (Infors AG, Bottmingen, Switzerland) for 1 week. The medium was composed of basal elements, trace elements and vitamins according to [39-41]: (a) Basal elements: Glucose $56 \mathrm{mM}$, Ammonium tartrate $1.19 \mathrm{mM}, \mathrm{KH}_{2} \mathrm{PO}_{4} 7.35 \mathrm{mM}$, $\mathrm{MgSO}_{4} \cdot 7 \mathrm{H}_{2} \mathrm{O} \quad 2.02 \mathrm{mM}, \quad \mathrm{CaCl}_{2} \cdot 2 \mathrm{H}_{2} \mathrm{O} \quad 0.68 \mathrm{mM}$, $\mathrm{FeSO}_{4} \cdot 7 \mathrm{H}_{2} 06.47 \times 10^{-2} \mathrm{mM}$, Nitrilotriacetate $7.85 \mu \mathrm{M}$; (b) Trace elements: $\mathrm{MnSO}_{4} \cdot \mathrm{H}_{2} \mathrm{O} \quad 5.92 \mu \mathrm{M}, \quad \mathrm{CoCl}_{2} \cdot 6 \mathrm{H}_{2} \mathrm{O}$ $4.20 \mu \mathrm{M}, \mathrm{ZnSO}_{4} \cdot 7 \mathrm{H}_{2} \mathrm{O} 10.4 \mu \mathrm{M}, \mathrm{CuSO}_{4} \cdot 5 \mathrm{H}_{2} \mathrm{O} 0.04 \mu \mathrm{M}$, $\mathrm{AlK}\left(\mathrm{SO}_{4}\right)_{2} 2.28 \times 10^{-2} \mu \mathrm{M}, \mathrm{H}_{3} \mathrm{BO}_{3} 0.162 \mu \mathrm{M}, \mathrm{Na}_{2} \mathrm{MoO}_{4}$ $4.86 \times 10^{-2} \mu \mathrm{M}$; (c) Vitamins: Biotin $8.19 \mathrm{nM}$, Folic acid $4.53 \mathrm{nM}$, Thiamine hydrochloride (B1) $0.148 \mu \mathrm{M}$, Riboflavin $0.133 \mu \mathrm{M}$, Pyridoxine hydrochloride (B6) $48.6 \mu \mathrm{M}$, Cyanocobalamin (B12) $7.38 \times 10^{-2} \mathrm{nM}$, Nicotinic acid 40.6 $\mathrm{nM}, \mathrm{D}$-Calcium pantothenate $20.9 \mathrm{nM}, \mathrm{p}$-Aminobenzoic acid $36.5 \mathrm{nM}$, Thioctic acid $24.2 \mathrm{nM}$. The $\mathrm{pH}$ of the basal elements solution was adjusted to 4.5 with $20 \%(\mathrm{~m} / \mathrm{v})$
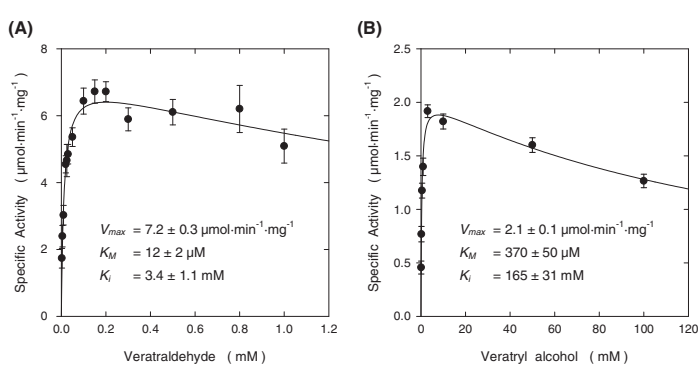

Figure 5 Kinetic parameters of recombinant PC Aad1p for Veratraldehyde and Veratryl alcohol. The kinetic parameters of the $P C$ Aad1 enzyme were determined for (A) the reduction reaction of Veratraldehyde and (B) the oxidation reaction of Veratryl alcohol. Activities were measured at $30^{\circ} \mathrm{C}$ in $50 \mathrm{mM}$ MES buffer at $\mathrm{pH} 6.1$ containing $0.3 \mathrm{mM} \mathrm{NADPH}$ in the reduction sense and in $100 \mathrm{mM} \mathrm{Glycine-KOH}$ buffer at pH 10.3 with $0.3 \mathrm{mM} \mathrm{NADP}^{+}$for the oxidation reactions. The kinetic parameters for other substrates are presented in Table 2. Results are the mean \pm SEM from at least three separate experiments. 
$\mathrm{NaOH}$. Trace elements and vitamins were prepared in 10000 -fold concentrated stock solutions and added to the basal solution after autoclaving at $120^{\circ} \mathrm{C}$ for $20 \mathrm{~min}$.

\section{Analysis by qPCR of Phanerochaete chrysosporium AAD1 gene expression}

The expression of Pc AAD1 during Nitrogen-limited cultivation was analyzed by real-time PCR (qPCR). The frozen mycelia were disrupted with TissueLyser II grinder for $2 \times 1.5 \mathrm{~min}$ at $30 \mathrm{~s}^{-1}$ frequency (Qiagen SAS, Courtaboeuf, France) and total RNA was purified from c.a. $100 \mathrm{mg}$ wet-mycelium with the RNeasy Plant Mini Kit (Qiagen) according to the manufacturer's instructions. The quality of the extracted RNA was determined using the Bioanalyzer 2100 with the RNA 6000 Nano LabChip kit (Agilent Technologies, Massy, France) and quantified in the NanoDrop ND-1000 UV-visible light spectrophotometer (Fisher Scientific SAS, Illkirch, France). cDNA was then synthesized from an exact amount of $1 \mu \mathrm{g}$ total RNA in $20 \mu \mathrm{L}$ reaction mixtures using the iScript ${ }^{\mathrm{TM}}$ cDNA Synthesis Kit (Bio-Rad, Marnes-la-Coquette, France). Real-time PCR reactions were carried out using a MyiQ Single-Color Real-Time PCR Detection System (Bio-Rad). The $\beta$-Tubulin transcript coded by scaffold_10:459524-461702 was amplified in parallel with the target $A A D 1 \mathrm{cDNA}$ and used as reference for normalization of gene expression. The stable $\mathrm{Ct}$ values observed for this gene among the different samples reflects the stability of its expression under the conditions tested. Primer sequences were as follows: AAD1-2-3-F2 (5' ${ }^{\prime}$ TCGTTGCTACCAAGTACAGTCTG GTCTACAAACGGGG-3') and AAD1-3-4-R2 (5'-GCG ATGGCCATCCCTTCGTGAATGCACA-3') for target gene Pc AAD1; $\mathrm{x}$ BTUB-N-Term-F (5' -ATCGGTGCCA AGTTCTGGGAGGT-3') and BTUB-N-Term-R (5'-TG TTCGCGCCAACTTCGTTGTAGT-3') for reference gene. Reactions were performed in $25 \mu \mathrm{L}$ final reaction volume using $\mathrm{iQ}^{\mathrm{TM}} \mathrm{SYBR}^{\circledR}$ Green Supermix (Bio-Rad), $0.1 \mu \mathrm{M}$ final concentration of each primer and $1 \mu \mathrm{L}$ of the cDNA preparation. The $\mathrm{qPCR}$ conditions were as follows: 1 cycle $\left(95^{\circ} \mathrm{C}\right.$ for $\left.3 \mathrm{~min}\right), 40$ cycles $\left(95^{\circ} \mathrm{C}\right.$ for $16 \mathrm{~s}$, and $58^{\circ} \mathrm{C}$ for $30 \mathrm{~s}$ ). Reactions were set up in triplicate for each of four biological replicates to ensure the reliability of the results. The absence of genomic DNA in RNA samples was checked by real-time PCR before cDNA synthesis. Melting curves $\left(55-95^{\circ} \mathrm{C}\right.$, in $0.5^{\circ} \mathrm{C}$ increments for $30 \mathrm{~s}$ ) were performed at the end of the qPCR reaction to verify the specificity of the amplification products and the absence of primer dimers.

\section{RACE cloning of $A A D 1$ CDNA from Phanerochaete chrysosporium}

The relative expression level of $A A D 1$ gene in $P$. chrysosporium being maximum after six days of cultivation in nitrogen-limited liquid medium, fungus pellets were harvested at this physiological state, filtered, washed twice with water and frozen in liquid nitrogen. The frozen mycelia were disrupted $2 \times 1.5 \mathrm{~min}$ at $30 \mathrm{~s}^{-1}$ frequency with TissueLyser II grinder (Qiagen SAS, Courtaboeuf, France) and total RNA was purified from c.a. $100 \mathrm{mg}$ wet-mycelium with the RNeasy Plant Mini Kit (Qiagen). In order to clone the $P$. chrysosporium AAD1 full-length cDNA, 5' - rapid amplification of cDNA ends (RACE) and 3'-RACE were performed with the SMART ${ }^{\mathrm{TM}}$ RACE CDNA amplification kit from Clontech (Ozyme, Saint-Quentin-enYvelines, France). After separate synthesis by reverse transcription, $5^{\prime}$ - and $3^{\prime}$-RACE cDNA fragments were amplified by touchdown PCR in independent reactions with the gene specific primers AAD1-3-4-R2 (5' GCGATGGCCATCCCTTCGTGAATGCACA-3') and AAD1-2-3-F2 (5' -TCGTTGCTACCAAGTACAGTCT GGTCTACAAACGGGG-3'), respectively. Touchdown PCR conditions were as follows: 5 cycles $\left(94^{\circ} \mathrm{C}\right.$ for 30 $\mathrm{s}, 72^{\circ} \mathrm{C}$ for $\left.3 \mathrm{~min}\right), 5$ cycles $\left(94^{\circ} \mathrm{C}\right.$ for $30 \mathrm{~s}, 70^{\circ} \mathrm{C}$ for $30 \mathrm{~s}$ and $72^{\circ} \mathrm{C}$ for $3 \mathrm{~min}$ ); then 25 cycles $\left(94^{\circ} \mathrm{C}\right.$ for $30 \mathrm{~s}, 68^{\circ} \mathrm{C}$ for $30 \mathrm{~s}$, and $72^{\circ} \mathrm{C}$ for $3 \mathrm{~min}$ ). The resulting amplicons were cloned into pGEM $^{\circledR}$-T Easy vector (Promega, Charbonnieres, France). The full-length $P c A A D 1$ ORF was obtained by overlapping PCR using Phusion ${ }^{\circledR}$ High-Fidelity DNA Polymerase (Ozyme, Saint-Quentinen-Yvelines, France), the $5^{\prime}$ - and $3^{\prime} \mathrm{RACE}$ cloned fragments as templates and the AAD1-ORF-Start-F (5' -ATGAACA TCTGGGCACCCGCA-3') and AAD1-ORF-End-R (5' CTACTTCTGGGGGCGGATAGC-3') primers. Thermal cycling conditions were: 1 cycle at $95^{\circ} \mathrm{C}$ for $4 \mathrm{~min}$, followed by 25 cycles of $95^{\circ} \mathrm{C}$ for $30 \mathrm{~s}, 68^{\circ} \mathrm{C}$ for $30 \mathrm{~s}$ and $72^{\circ} \mathrm{C}$ for $3 \mathrm{~min}$. The resulting PCR product was cloned into the $\mathrm{pGEM}^{\circledR}$-T Easy vector (Promega). All PCR products were A-tailed before cloning into $\mathrm{pGEM}^{\circledR}$-T Easy vector and transferring into chemically competent $E$. coli DH5 $\alpha$ cells (Invitrogen ${ }^{\mathrm{TM}}$, Life Technologies SAS, Saint Aubin, France). The inserts were sequenced at Beckman Coulter Genomics (Grenoble, France).

\section{Expression and purification of PC AAD1 ORF in Escherichia coli}

The full-length $P C$ AAD1 ORF obtained by RACE cloning was amplified by Phusion ${ }^{\circledR}$ DNA polymerase PCR with primers BamHI-Start-F (5'-CCTGGGATC CATGAACATCTGGGCACCCGCA-3') and NotI-No Stop-R(5' -GAGCGGCCGCCTTCTGGGGGCGGATA GCCTG-3') in order to generate BamHI and NotI sites (underlined in the sequence) respectively at $5^{\prime}$ and $3^{\prime}$ of the $A A D 1$ ORF and cloned in $\mathrm{pGEM}^{\circledR}$-T Easy vector (Promega). PCR conditions were: 1 cycle $\left(98^{\circ} \mathrm{C}\right.$ for $\left.30 \mathrm{~s}\right), 30$ cycles $\left(98^{\circ} \mathrm{C}\right.$ for $10 \mathrm{~s}, 65^{\circ} \mathrm{C}$ for $30 \mathrm{~s}$ and $72^{\circ} \mathrm{C}$ for $\left.45 \mathrm{~s}\right)$; then 1 cycle $\left(72^{\circ} \mathrm{C}\right.$ for $\left.7 \mathrm{~min}\right)$. Insert was excised from vector by 
digestion with BamHI and NotI and directionally subcloned into the expression vector pGS-21a (GenScript) previously digested with the same restriction enzymes. The resulting construct, termed pGS-21a- $A A D 1$, was sequenced to verify that the PCR reaction had not introduced any mutations. This expression plasmid encoded the recombinant fusion protein containing a $\mathrm{His}_{6}$-GST tag at the $\mathrm{N}$-terminus and a $\mathrm{His}_{6}$ tag at the $\mathrm{C}$-terminus.

Three E. coli strains BL21 Star ${ }^{\text {TM }}$ (DE3) (Invitrogen ${ }^{\mathrm{TM}}$, Life Technologies SAS, Saint Aubin, France), BL21(DE3) and BL21- CodonPlus(DE3)-RIL (Stratagene, Agilent Technologies, Massy, France) were tested as expression hosts after transformation with plasmid pGS-21a-AAD1. Overnight cultures of the transformants made in LB medium containing the appropriate antibiotic(s) at $37^{\circ} \mathrm{C}$ were used to inoculate $150 \mathrm{~mL}$ of the same medium in $1 \mathrm{~L}$ Erlenmeyer flasks at an initial $\mathrm{OD}_{600}$ of 0.1 . The bacterial biomass was grown at $37^{\circ} \mathrm{C}$ and $100 \mathrm{rpm}$ until $\mathrm{OD}_{600}$ 0.7-0.9. The production of the recombinant protein was induced by addition of Isopropyl $\beta$-D-1-thiogalactopyranoside (IPTG) at $0.1 \mathrm{mM}$ final concentration followed by incubation at $16^{\circ} \mathrm{C}$ and $120 \mathrm{rpm}$ for $12 \mathrm{~h}$. Bacterial cells were collected by centrifugation $\left(4^{\circ} \mathrm{C}, 10000 \mathrm{~g}, 1 \mathrm{~min}\right)$, resuspended in PBS buffer at $\mathrm{pH} 7.3$ containing $200 \mu \mathrm{g} \cdot \mathrm{mL}^{-}$

${ }^{1}$ Lysozyme and disrupted by sonication (ten $30 \mathrm{~s}$ pulses with a Vibra Cell $^{\mathrm{TM}} 72434$ ultrasonicator operating at $35 \%$ power in $25 \mathrm{~W}$ scale). After addition of Triton ${ }^{\circledR} \mathrm{X}-100$ at $1 \%(\mathrm{v} / \mathrm{v})$ final concentration, the cell lysate was left on ice for $20 \mathrm{~min}$ and centrifuged $\left(4^{\circ} \mathrm{C}, 10000 \mathrm{~g}, 20 \mathrm{~min}\right)$ to remove cell debris.

The recombinant $P_{c}$ Aad1p fusion protein was purified by a single-step batch affinity chromatography process on Glutathione Sepharose ${ }^{\text {TM }} 4 \mathrm{~B}$ previously equilibrated with PBS buffer at pH 7.3 according to the manufacturer's instructions. The Glutathione Sepharose ${ }^{\mathrm{TM}} 4 \mathrm{~B}$ beads $(0.75 \mathrm{~mL})$ were added to the cell lysate supernatant $(15 \mathrm{~mL})$ and incubated $2 \mathrm{~h}$ at $4^{\circ} \mathrm{C}$ under gentle agitation (end-over-end rotation) in $50 \mathrm{~mL}$ Falcon ${ }^{\mathrm{TM}}$ Conical Tubes (BD Biosciences, NJ, USA). Non-adsorbed proteins were removed by washing the beads with $\mathrm{PBS}$ buffer at $\mathrm{pH} 7.3$ several times until the Bradford assay for protein did not react any more. The recombinant protein was eluted with $50 \mathrm{mM}$ Tris- $\mathrm{HCl}, \mathrm{pH} 8.0$, containing $10 \mathrm{mM}$ reduced L-Glutathione and stored at $4{ }^{\circ} \mathrm{C}$.

\section{Enzyme assays}

Enzymatic activity of $P c$ Aad1p was determined spectrophotometrically using an Agilent HP 8453 UV-visible spectrophotometer (Agilent Technologies, Massy, France). Unless otherwise specified, all assays were carried out at $30^{\circ} \mathrm{C}$ in $1 \mathrm{~mL}$ reaction mixtures using $1 \mathrm{~cm}$ optical path length microcuvettes. Reactions were initiated by substrate addition and were monitored by recording the absorption at
$355 \mathrm{~nm}$. At this wavelength, the molar extinction coefficients of the substrate compounds could be considered as negligible (less than 4\%) compared to that of $\operatorname{NAD}(\mathrm{P}) \mathrm{H}\left(\epsilon_{355}=5.12 \mathrm{mM}^{-1} \cdot \mathrm{cm}^{-1}\right)$. The effect of $\mathrm{pH}$ was studied at $30^{\circ} \mathrm{C}$, using $25 \mathrm{mM}$ MES $(\mathrm{pH}$ 5.5 - 6.4), $50 \mathrm{mM}$ HEPES ( $\mathrm{pH} 6.9$ - 8.2), $25 \mathrm{mM}$ Tris$\mathrm{HCl}(\mathrm{pH} 8.8)$ or $100 \mathrm{mM}$ Glycine-KOH $(\mathrm{pH}$ $9.0-10.7)$ as buffers. The temperature dependence was evaluated in $50 \mathrm{mM}$ MES buffer ( $\mathrm{pH}$ 6.1) in the presence of $0.2 \mathrm{mM}$ 3,4-Dimethoxybenzaldehyde and $0.2 \mathrm{mM} \mathrm{NADPH}$ and the reaction was started by adding $9.0 \mu \mathrm{g}$ of the enzyme. The substrate specificity towards a range of substrates (Table 1) and the kinetic parameters determinations (Table 2) were determined in $50 \mathrm{mM}$ MES buffer ( $\mathrm{pH}$ 6.1) using $0.3 \mathrm{mM}$ $\mathrm{NADPH}$ and $1 \mathrm{mM}$ substrate in the reduction sense, or in $100 \mathrm{mM}$ Glycine-KOH buffer ( $\mathrm{pH}$ 10.3) using $0.3 \mathrm{mM} \mathrm{NADP}{ }^{+}$and $10 \mathrm{mM}$ substrate (except for Octanol where $1 \mathrm{mM}$ was used, and for 2Chlorobenzyl alcohol and 4-Chlorobenzyl alcohol where $3 \mathrm{mM}$ were used) for the oxidation sense. The specific activity towards 3,4-Dimethoxybenzaldehyde $\left(5.1 \mu \mathrm{mol} \cdot \mathrm{min}^{-1} \cdot \mathrm{mg}^{-1}\right)$ and to 3,4-Dimethoxybenzyl alcohol $\left(2.0 \mu \mathrm{mol} \cdot \mathrm{min}^{-1} \cdot \mathrm{mg}^{-1}\right)$ were taken as $100 \%$ for the reduction and oxidation reactions, respectively (Table 1).

The kinetic parameters $K_{M}, k_{\text {cat }}$ and $K_{i}$ for aldehyde and alcohol substrates (Table 2) were computed by fitting initial reaction rates, measured as a function of substrate concentration, to the Michaelis-Menten equation (Equation 1) or, when substrate inhibition was observed, to the uncompetitive substrate inhibition equation (Equation 2) with the non-linear regression Enzyme Kinetics 1.3 module of the SigmaPlot 11.0 package (Systat Software, IL, USA):

$$
\begin{aligned}
& V=V_{\max }[S] /\left(K_{M}+[S]\right) \\
& V=V_{\max }[S] /\left(K_{M}+[S]+[S]^{2} / K_{i}\right)
\end{aligned}
$$

where $V$ represents the reaction rate, $V_{\max }$ is the limiting reaction rate, $S$ is the substrate concentration, $K_{M}$ is the Michaelis constant and $K_{i}$ is the substrate inhibition constant. The catalytic constant $k_{\text {cat }}$ of the enzyme for the different substrates was derived from $k_{c a t}=V_{\max } /[E]$. The total enzyme concentration $[E]$ was evaluated using a protein molecular mass of $74.2 \mathrm{kDa}$. The enzyme kinetic parameters for $\mathrm{NAD}(\mathrm{P}) \mathrm{H}$ and $\mathrm{NAD}(\mathrm{P})^{+}+$were determined with $0.2 \mathrm{mM}$ 3,4-Dimethoxybenzaldehyde and $10 \mathrm{mM}$ 3,4-Dimethoxybenzyl alcohol, respectively. Results are the mean \pm SEM from at least three separate experiments.

\section{Abbreviations}

AAD: Aryl-alcohol dehydrogenase; AAO: Aryl-alcohol oxidase; ADH: Alcohol dehydrogenase; AKR: Aldo-keto reductase; GST: Glutathione S-Transferase; His $_{6}$ : Hexahistidine; IPTG: Isopropyl $\beta$-D-1-thiogalactopyranoside; LiP: Lignin peroxidise; MnP: Manganese-dependent peroxidise; PC: Phanerochaete 
chrysosporium; RACE: Rapid Amplification of cDNA Ends; PCR: Polymerase Chain Reaction; PDA: Potato Dextrose Agar; qPCR: Real-Time PCR.

\section{Competing interests}

The authors declare that they have no competing interests.

\section{Authors' contribution}

DDY participated in the design of the study, carried out the experimental work, participated in the interpretation of the results and drafted the manuscript. JMF participated in the design and coordination of this study and helped to revise the manuscript. GMdB conceived and designed the study, coordinated the experiments, interpreted the results and revised the manuscript for important intellectual content. All authors read and approved the final manuscript.

\section{Acknowledgements}

We are very grateful to Jean-Luc PARROU and Emmanuelle TREVISIOL for scientific support and to Marie-Ange TESTE and Pierre ESCALIER for technical assistance. Dong- Dong YANG holds a Ph. D. grant from the China Scholarship Council. This work was supported in part by Region Midi Pyrénées (France) under Grant No. 09005247 and was carried out in the frame of COST Action FA0907 BIOFLAVOUR (www.bioflavour.insa- toulouse.fr) under the EU's Seventh Framework Programme for Research (FP7).

\section{Author details}

'Université de Toulouse; INSA, UPS, INP; LISBP, 135 Avenue de Rangueil, Toulouse F-31077, France. ${ }^{2}$ INRA, UMR792 Ingénierie des Systèmes Biologiques et des Procédés, Toulouse F-31400, France. ${ }^{3}$ CNRS, UMR5504, Toulouse F-31400, France. ${ }^{4}$ INP-ENSAT, Avenue de I'Agrobiopole, Castanet-Tolosan Cedex F-31326, France.

Received: 1 February 2012 Accepted: 16 April 2012 Published: 28 June 2012

\section{References}

1. Boerjan W, Ralph J, Baucher M: Lignin biosynthesis. Annu Rev Plant Biol 2003, 54:519-546.

2. Martinez D, Larrondo LF, Putnam N, Gelpke MDS, Huang K, Chapman J, Helfenbein KG, Ramaiya P, Detter JC, Larimer F, Coutinho PM, Henrissat B, Berka R, Cullen D, Rokhsar D: Genome sequence of the lignocellulose degrading fungus Phanerochaete chrysosporium strain RP78. Nat Biotechnol 2004, 22:695-700.

3. Glenn JK, Gold MH: Purification and characterization of an extracellular $\mathrm{Mn}(\mathrm{II})$ - dependent peroxidase from the lignin-degrading basidiomycete. Phanerochaete chrysosporium. Arch Biochem Biophys 1985, 242:329-341.

4. Tien M, Kirk TK: Lignin-Degrading Enzyme from the Hymenomycete Phanerochaete chrysosporium Burds. Science 1983, 221:661-663.

5. Banci L, Ciofi-Baffoni S, Tien M: Lignin and Mn peroxidase-catalyzed oxidation of phenolic lignin oligomers. Biochemistry 1999, 38:3205-3210.

6. Kersten P, Cullen D: Extracellular oxidative systems of the lignindegrading Basidiomycete Phanerochaete chrysosporium. Fungal Genet Biol 2007, 44:77-87.

7. Kersten PJ, Kirk TK: Involvement of a new enzyme, glyoxal oxidase, in extracellular $\mathrm{H} 2 \mathrm{O} 2$ production by Phanerochaete chrysosporium. J Bacteriol 1987, 169:2195-2201.

8. Kersten PJ: Glyoxal oxidase of Phanerochaete chrysosporium: its characterization and activation by lignin peroxidase. Proc Natl Acad Sci U S A 1990, 87:2936-2940.

9. Whittaker MM, Kersten PJ, Cullen D, Whittaker JW: Identification of catalytic residues in glyoxal oxidase by targeted mutagenesis. J Biol Chem 1999, 274:36226-36232.

10. Varela E, Guillén F, Martínez AT, Martínez MJ: Expression of Pleurotus eryngii aryl- alcohol oxidase in Aspergillus nidulans: purification and characterization of the recombinant enzyme. Biochim Biophys Acta 2001, 1546:107-113

11. Harvey PJ, Schoemaker HE, Palmer JM: Veratryl alcohol as a mediator and the role of radical cations in lignin biodegradation by Phanerochaete chrysosporium. FEBS Lett 1986, 195:242-246.
12. Jensen KA, Evans KM, Kirk TK, Hammel KE: Biosynthetic Pathway for Veratryl Alcohol in the Ligninolytic Fungus Phanerochaete chrysosporium. Appl Environ Microbiol 1994, 60:709-714.

13. Guillén F, Martínez AT, Martínez MJ, Evans CS: Hydrogen-peroxideproducing system of Pleurotus eryngii involving the extracellular enzyme aryl-alcohol oxidase. Appl Microbiol Biotechnol 1994, 41:465-470

14. Guillén F, Evans CS: Anisaldehyde and Veratraldehyde Acting as Redox Cycling Agents for $\mathrm{H} 2 \mathrm{O} 2$ Production by Pleurotus eryngii. Appl Environ Microbiol 1994, 60:2811-2817.

15. Gutiérrez A, Caramelo L, Prieto A, Martínez MJ, Martínez AT: Anisaldehyde production and aryl-alcohol oxidase and dehydrogenase activities in ligninolytic fungi of the genus Pleurotus. Appl Environ Microbiol 1994, 60:1783-1788.

16. Varela E, Jesús Martínez M, Martínez AT: Aryl-alcohol oxidase protein sequence: a comparison with glucose oxidase and other FAD oxidoreductases. Biochim Biophys Acta 2000, 1481:202-208

17. Martínez AT, Speranza M, Ruiz-Dueñas FJ, Ferreira P, Camarero S, Guillén F, Martínez MJ, Gutiérrez A, del Río JC: Biodegradation of lignocellulosics: microbial, chemical, and enzymatic aspects of the fungal attack of lignin. Int Microbiol 2005, 8:195-204.

18. Ambert-Balay K, Fuchs SM, Tien M: Identification of the veratryl alcohol binding site in lignin peroxidase by site-directed mutagenesis. Biochem Biophys Res Commun 1998, 251:283-286.

19. Muheim A, Waldner R, Sanglard D, Reiser J, Schoemaker HE, Leisola MS: Purification and properties of an aryl-alcohol dehydrogenase from the white-rot fungus Phanerochaete chrysosporium. Eur J Biochem 1991, 195:369-375.

20. Reiser J, Muheim A, Hardegger M, Frank G, Fiechter A: Aryl-alcohol dehydrogenase from the white-rot fungus Phanerochaete chrysosporium. Gene cloning, sequence analysis, expression, and purification of the recombinant enzyme. J Biol Chem 199, 269:28152-28159.

21. Phanerochaete chrysosporium v2.0 - Home. [http://genome.jgi- psf.org/ Phchr1/Phchr1.home.html]

22. Almeida JR, Modig T, Petersson A, Hähn-Hägerdal B, Lidén G, GorwaGrauslund MF: Increased tolerance and conversion of inhibitors in lignocellulosic hydrolysates by Saccharomyces cerevisiae. J Chem Technol Biotechnol 2007, 82:340-349.

23. Frohman MA, Dush MK, Martin GR: Rapid Production of Full-Length cDNAs from Rare Transcripts: Amplification Using a Single Gene-Specific Oligonucleotide Primer. PNAS 1988, 85:8998-9002.

24. Frohman MA: On Beyond Classic RACE (rapid Amplification of CDNA Ends). Genome Res 1994, 4:S40-S58.

25. Punta M, Coggill PC, Eberhardt RY, Mistry J, Tate J, Boursnell C, Pang N Forslund K, Ceric G, Clements J, Heger A, Holm L, Sonnhammer ELL, Eddy SR, Bateman A, Finn RD: The Pfam protein families database. Nucleic Acids Res 2011.

26. Pfam: Home page: [http://pfam.sanger.ac.uk/]

27. Hyndman D, Bauman DR, Heredia W, Penning TM: The aldo-keto reductase superfamily homepage. Chem Biol Interact 2003, 143-144:621-631.

28. Drury JE, Hyndman D, Jin Y, Penning TM: The Aldo-Keto Reductase Superfamily Homepage: 2006 Update. In Enzymology and Molecular Biology of Carbonyl Metabolism. Edited by Weiner H, Maser E, Lindahl R, Plapp B: Purdue University Press; 2007.

29. AKR Superfamily: [http://www.med.upenn.edu/akr/]

30. Davidson WS, Flynn TG: Kinetics and mechanism of action of aldehyde reductase from pig kidney. Biochem J 1979, 177:595-601.

31. Grimshaw CE, Shahbaz M, Putney CG: Mechanistic basis for nonlinear kinetics of aldehyde reduction catalyzed by aldose reductase. Biochemistry 1990, 29:9947-9955.

32. Askonas LJ, Ricigliano JW, Penning TM: The kinetic mechanism catalysed by homogeneous rat liver 3 alpha-hydroxysteroid dehydrogenase. Evidence for binary and ternary dead-end complexes containing non-steroidal anti-inflammatory drugs. Biochem J 1991, 278(Pt 3):835-841.

33. Yoshida M, Kuroki Y, Kobayashi E, Tamaoki B: Kinetic mechanism of reduction of testosterone by hepatic 5 beta-reductase of chicken and inhibition of the reductase activity by a secosteroid, an azasteroid and glycyrrhetinic acid. J Steroid Biochem Mol Biol 1992, 41:29-36. 
34. Jez JM, Bennett MJ, Schlegel BP, Lewis M, Penning TM: Comparative anatomy of the aldo-keto reductase superfamily. Biochem J 1997, 326(Pt 3):625-636.

35. Larroy C, Fernández MR, González E, Parés X, Biosca JA: Characterization of the Saccharomyces cerevisiae YMR318C (ADH6) gene product as a broad specificity NADPH-dependent alcohol dehydrogenase: relevance in aldehyde reduction. Biochem J 2002, 361:163-172.

36. Larroy C, Parés X, Biosca JA: Characterization of a Saccharomyces cerevisiae NADP(H)-dependent alcohol dehydrogenase (ADHVII), a member of the cinnamyl alcohol dehydrogenase family. Eur J Biochem 2002, 269:5738-5745.

37. Larroy C, Rosario Fernández M, González E, Parés X, Biosca JA: Properties and functional significance of Saccharomyces cerevisiae ADHVI. Chem Biol Interact 2003, 143-144:229-238.

38. Bradford MM: A rapid and sensitive method for the quantitation of microgram quantities of protein utilizing the principle of protein-dye binding. Anal Biochem 1976, 72:248-254.

39. Waldner R, Leisola MSA, Fiechter A: Comparison of ligninolytic activities of selected white-rot fungi. Appl Microbiol Biotechnol 1988, 29:400-407.

40. Janshekar $\mathrm{H}$, Haltmeier T, Brown C: Fungal degradation of pine and straw alkali lignins. Eur J Appl Microbiol Biotechnol 1982, 14:174-181.

41. Kirk TK, Schultz E, Connors WJ, Lorenz LF, Zeikus JG: Influence of culture parameters on lignin metabolism by Phanerochaete chrysosporium. Arch Microbiol 1978, 117:277-285.

doi:10.1186/1471-2180-12-126

Cite this article as: Yang et al:: Cloning, expression and characterization of an aryl-alcohol dehydrogenase from the white-rot fungus

Phanerochaete chrysosporium strain

BKM-F-1767. BMC Microbiology 2012 12:126.

\section{Submit your next manuscript to BioMed Central and take full advantage of:}

- Convenient online submission

- Thorough peer review

- No space constraints or color figure charges

- Immediate publication on acceptance

- Inclusion in PubMed, CAS, Scopus and Google Scholar

- Research which is freely available for redistribution 